\title{
Beyond the immediate tumor microenvironment: distinct $T$ cell phenotype and function of tumor- adjacent healthy breast tissue associated with regional metastasis in breast cancer
}

\author{
Yi Guo ${ }^{1}$, Alfred Chan ${ }^{1}$, Ingrid Cely ${ }^{1}$, Jaime Shamonki ${ }^{2}$, Michelle Kinnaird ${ }^{3}$, Maggie DiNome ${ }^{1}$, \\ Begonya Comin-Anduix ${ }^{4}$, Peter Sieling ${ }^{5^{*}}$, Delphine Lee ${ }^{1}$
}

From Society for Immunotherapy of Cancer 29th Annual Meeting

National Harbor, MD, USA. 6-9 November 2014

While current breast cancer staging includes lymph node involvement as a key indicator of prognosis, little is known about how healthy tissue surrounding the immediate tumor microenvironment contributes to the loco-regional spread of disease. Previous studies of the role of the immune microenvironment in breast cancer have focused on the study of intratumoral $\mathrm{T}$ cells, reporting that increased intratumoral CD8 $+\mathrm{T}$ cell proportions with decreased $\mathrm{CD} 4+\mathrm{T}$ cell proportions are associated with lymph node metastasis and rapid tumor progression. We hypothesized that $\mathrm{T}$ cells within the unaffected breast tissue ("healthy-adjacent" tissue) near the tumor (2-5 cm away from the tumor margin) may influence the local/regional spread of tumor cells. Since the amount of tissue available for study from the excision of primary tumors is limited, we utilized a previously established three-dimensional explant method to expand resident $\mathrm{T}$ cells from fresh breast cancer and healthy-adjacent breast tissue to investigate their phenotypic and functional qualities. We compared tissues from patients with $\mathrm{LN}$ metastasis $(\mathrm{n}=8)$ and those without LN involvement $(n=7)$. We defined the surface phenotype of $\mathrm{T}$ cells derived from breast cancer and healthy-adjacent tissue using multiparameter flow cytometry. We found that healthy-adjacent tissue from patients with LN metastases exhibited a 1.6 fold lower percentage of CD4 T cells $(\mathrm{p}<0.01)$ and 3.7 fold higher percentage of CD8 $\mathrm{T}$ cells $(\mathrm{p}<0.05)$ than patients with no LN involvement. In contrast, we did not find any statistically

John Wayne Cancer Institute, Santa Monica, CA, USA

Full list of author information is available at the end of the article significant differences in the number of intratumoral CD4 and CD8 T cells in patients with $\mathrm{LN}$ metastases versus those with no LN involvement. We hypothesized that qualitative $\mathrm{T}$ cell cytokine response from the surrounding healthy adjacent tissue may also be associated with LN metastases. Our preliminary data from the study of breast cancer patients $(n=6)$ showed some trends of increased Th2 cytokine and decreased pro-inflammatory cytokine associated with nodal metastases. These data suggest that the tissue extending beyond the tumor microenvironment (healthy-adjacent tissue) may contribute to immune surveillance and regional metastases. While this study size is small, it demonstrates the feasibility of using the explant method to interrogate healthy-appearing tumor adjacent tissue to investigate the surrounding breast tissue environment. Our preliminary findings also indicate the potential relevance of investigating the role of $\mathrm{T}$ cells in tumor adjacent healthyappearing breast tissue to provide tumor immune surveillance. Further analysis of the T cells present in healthy adjacent breast tissue is warranted.

\section{Consent}

Written informed consent was obtained from the patient for publication of this abstract and any accompanying images. A copy of the written consent is available for review by the Editor of this journal.

\section{Authors' details \\ 'John Wayne Cancer Institute at Providence Saint John's Health Center, Santa Monica, CA, USA. ${ }^{2}$ California Cryobank, CA, USA. ${ }^{3}$ Department of Pathology, Providence Saint John's Health Center, Santa Monica, CA, USA.}


Published: 6 November 2014

doi:10.1186/2051-1426-2-S3-P269

Cite this article as: Guo et al.: Beyond the immediate tumor

microenvironment: distinct T cell phenotype and function of tumor-

adjacent healthy breast tissue associated with regional metastasis in breast

cancer. Journal for ImmunoTherapy of Cancer 2014 2(Suppl 3):P269.

Submit your next manuscript to BioMed Central and take full advantage of:

- Convenient online submission

- Thorough peer review

- No space constraints or color figure charges

- Immediate publication on acceptance

- Inclusion in PubMed, CAS, Scopus and Google Scholar

- Research which is freely available for redistribution

Submit your manuscript at www.biomedcentral.com/submit 